\title{
Geographical distribution of three oceanic Halobates spp. and an account of the behaviour of $\boldsymbol{H}$. sericeus (Heteroptera: Gerridae)
}

\author{
TETSUO HARADA \\ Laboratory of Environmental Physiology, Faculty of Education, Kochi University, Kochi 780-8520, Japan; \\ e-mail: haratets@cc.kochi-u.ac.jp
}

Key words. Gerridae, distribution, photoperiodism, aggregation, reproduction, Halobates

\begin{abstract}
Halobates spp. are the only insects inhabiting the open sea. One sea skater species, Halobates sericeus, was collected at 18 locations in the East China Sea area $\left(27^{\circ} 10^{\prime} \mathrm{N}-33^{\circ} 24^{\prime} \mathrm{N}, 124^{\circ} 57^{\prime} \mathrm{E}-129^{\circ} 30^{\prime} \mathrm{E}\right)$, and H. micans and/or H. germanus at only 8 locations in the area south of $29^{\circ} 47^{\prime} \mathrm{N}$, where water temperatures were more than $25^{\circ} \mathrm{C}$. At three locations, where the water temperature was less than $23^{\circ} \mathrm{C}$, neither $H$. micans nor H. germanus were caught. The effect of photoperiod on the aggregation and mating behaviour of the sea skater, $H$. sericeus, was studied under laboratory conditions during a one-month cruise. Adults and $5^{\text {th }}$ instar larvae of $H$. sericeus, collected between $29^{\circ} 02^{\prime} \mathrm{N}$ and $30^{\circ} 29^{\prime} \mathrm{N}$, were kept under long (14.5L : 9.5D) or short-day (10.5L : 13.5D) conditions at $23 \pm 2{ }^{\circ} \mathrm{C}$ for 20 days. Aggregation and mating behaviour of these sea skaters were recorded over a period of $150 \mathrm{~min}$ during the daytime. To analyze the data, the observation period of $150 \mathrm{~min}$ was divided into 50 intervals of 3 min. Aggregation was observed more under short than long-days. Duration of a group was much longer under the short (mean \pm SD : $43.0 \pm 108.1 \mathrm{sec}$ ) than long-days $(7.6 \pm 3.1 \mathrm{sec})$.
\end{abstract}

\section{INTRODUCTION}

The only insects that inhabit the open sea are five species of sea skaters: Halobates micans, H. sericeus, H. germanus, $H$. splendens, and H. sobrinus (Cheng, 1985). Three species, Halobates sericeus, $H$. micans and $H$. germanus inhabit tropical and temperate areas of the Pacific Ocean in the northern hemisphere, including The Kuroshio Current and the East China Sea (Andersen \& Polhemus, 1976; Cheng, 1985). Halobates sericeus, $H$. micans and $H$. germanus are reported from a latitudes of $13^{\circ} \mathrm{N}-40^{\circ} \mathrm{N}, 0^{\circ} \mathrm{N}-35^{\circ} \mathrm{N}$ and $0^{\circ} \mathrm{N}-37^{\circ} \mathrm{N}$, respectively, in the Pacific Ocean (Miyamoto \& Senta, 1960; Andersen \& Polhemus, 1976; Ikawa et al., 2002). However, this information was collected on different cruises and different times of the years. That is, there has not been ecological study based on samples collected in a specific area in a particular season.

Halobates sericeus could use day-length as a seasonal cue and anticipate seasonal variations in the environment. However, there are no experimental studies on the photoperiodic regulation of life-history traits, including reproduction and several other kinds of behaviour in this species, although the photoperiodic regulation of life history traits of many species of terrestrial Gerridae is well studied (Vepsäläinen, 1971, 1978; Spence, 1989; Harada \& Numata, 1993; Spence \& Andersen, 1994; Harada et al., 2000; Harada, 2003).

This paper presents information on the geographical distribution of three species of Halobates in the eastern region of the East China Sea at a specific period in spring and reports the change induced in its life history traits, including mating and other kinds of behaviour, in response to photoperiod.

\section{MATERIAL AND METHODS}

Samples (15 min at 3.0-3.5 knots) were collected from 9-20 May, 2002 using a NEUSTON NET (rectangular parallel pipes, width of the opening: $112 \mathrm{~cm}$ ) or ORI NET (round-shaped opening with a diameter of $150 \mathrm{~cm}$ ) trailed along on sea water surface 2-3 $\mathrm{m}$ from the side of the Hakuhomaru (3900 t), which is owned by the Ocean Research Institute, University of Tokyo. Samples were taken at 18 locations (16 using a NEUSTON and
2 a ORI net) in the area $27^{\circ} 10^{\prime} \mathrm{N}-33^{\circ} 24^{\prime} \mathrm{N}$ and $124^{\circ} 57^{\prime} \mathrm{E}-$ $129^{\circ} 30^{\prime}$ E (Fig. 1).

Adults and $5^{\text {th }}$ instar larvae were collected for an experiment at 3 locations: $29^{\circ} 02^{\prime} \mathrm{N}-127^{\circ} 23^{\prime} \mathrm{E}, 30^{\circ} 29^{\prime} \mathrm{N}-128^{\circ} 40^{\prime} \mathrm{E}$ and $29^{\circ} 89^{\prime} \mathrm{N}-129^{\circ} 00^{\prime} \mathrm{E}$, in the East-China Sea. They were placed in a round plastic aquarium $(30 \mathrm{~cm}$ in diameter, $15 \mathrm{~cm}$ in height) filled with sea water, and kept at a photoperiod of 14.5L: 9.5D or $10.5 \mathrm{~L}: 13.5 \mathrm{D}$ and $23 \pm 2^{\circ} \mathrm{C}$. These sea skaters were fed on adult flies of Lucilia illustris, which were replaced every $12 \mathrm{~h}$, when the sea water was also changed. During the 3-week rearing period, longevity and oviposition were monitored. Mating and aggregation behavior were observed and recorded at the end of the 3 weeks. Aggregation behaviour is characteristic of sea skaters and similar to that of a "skydiving team" (Fig. 2). Two to six adults are attached to one another by their legs and do not move. This behavior was observed with the naked eye over a period of $150 \mathrm{~min}$ from 14:00 to 16:30. The sea skaters were observed through a $3 \mathrm{~mm}$ diameter pinhole, which was pierced in the top of the box $\left(70 \times 70 \times 70 \mathrm{~cm}^{3}\right)$, placed over the top of the aquarium to cut out light from outside. Frequency of mating attempts and duration of copulations were recorded. The observation period of $150 \mathrm{~min}$ was divided into 50 sets of $3 \mathrm{~min}$ interval and the results obtained in these intervals were used to analyze the aggregation and the mating behaviour. Statistical analysis of the results was performed using software for PC of "SPSS Base 9.0J" (SPSS Inc. North Michigan Avenue, Chicago, IL 60611).

\section{RESULTS}

\section{Distribution}

Halobates sericeus were caught at all 18 locations, while $H$. micans and $H$. germanus were caught at only 8 locations in the area south of $29^{\circ} 47^{\prime} \mathrm{N}$. (Table 1) (Fig. 1). At 7 of the 8 locations, where all three species were caught, the water temperature was higher than $25^{\circ} \mathrm{C}$. The temperature at location $\mathrm{E} 8$ $\left(29^{\circ} 41^{\prime} \mathrm{N}\right)$, on the warm Kuroshio Current was relatively high, $27.0^{\circ} \mathrm{C}$. Number of individuals collected tended to be weakly 
TABLE 1. Number of Halobates collected at 18 locations in the eastern region of the East China Sea, 9-20.v.2002. N - total number of individuals collected; H.m. - Halobates micans; H.g. - Halobates germanus; H.s. - Halobates sericeus; Stat - station number; WT - water temperature; SS - area of water surface over which the NEUSTON or ORI nets were trailed by the ship; $\bigcirc$ caught; $\times$ - not caught.

\begin{tabular}{crccccccc}
\hline Latitude & $\mathrm{N}$ & H.m. & H.g. & H.s. & Stat & WT $\left({ }^{\circ} \mathrm{C}\right)$ & Time of day & S.S. $\left(\mathrm{m}^{2}\right)$ \\
\hline $27^{\circ} 10^{\prime}$ & 82 & $\bigcirc$ & $\bigcirc$ & $\bigcirc$ & M6 & 26.1 & $21: 37$ & 15803 \\
$28^{\circ} 19^{\prime}$ & 161 & $\bigcirc$ & $\bigcirc$ & $\bigcirc$ & I 1 & 26.1 & 22.37 & 15693 \\
$28^{\circ} 40^{\prime}$ & 19 & $\bigcirc$ & $\bigcirc$ & $\bigcirc$ & H1 & 26.1 & $17: 38$ & 17852 \\
$29^{\circ} 11^{\prime}$ & 6 & $\bigcirc$ & $\bigcirc$ & $\bigcirc$ & A8 & 25.1 & $1: 45$ & 23036 \\
$29^{\circ} 11^{\prime}$ & 74 & $\bigcirc$ & $\bigcirc$ & $\bigcirc$ & A $~$ & 25.8 & $23: 30$ & 14869 \\
$29^{\circ} 12^{\prime}$ & 23 & $\times$ & $\bigcirc$ & $\bigcirc$ & M & 25.0 & $10: 05$ & 13630 \\
$29^{\circ} 12^{\prime}$ & 2 & $\times$ & $\times$ & $\bigcirc$ & M3 & 25.0 & $10: 35$ & 12100 \\
$29^{\circ} 12^{\prime}$ & 6 & $\times$ & $\times$ & $\bigcirc$ & M3 & 25.0 & $10: 55$ & 13028 \\
$29^{\circ} 30^{\prime}$ & 16 & $\bigcirc$ & $\bigcirc$ & $\bigcirc$ & F1 & 25.8 & $14: 25$ & 19970 \\
$29^{\circ} 41^{\prime}$ & 65 & $\bigcirc$ & $\bigcirc$ & $\bigcirc$ & E8 & 27.0 & $21: 45$ & 17501 \\
$29^{\circ} 47^{\prime}$ & 58 & $\bigcirc$ & $\bigcirc$ & $\bigcirc$ & F4 & 23.5 & $20: 00$ & 14764 \\
$30^{\circ} 31^{\prime}$ & 13 & $\times$ & $\times$ & $\bigcirc$ & B3 & 25.1 & $22: 57$ & 24870 \\
$30^{\circ} 31^{\prime}$ & 31 & $\times$ & $\bigcirc$ & $\bigcirc$ & B3 & 24.9 & $2: 18$ & 12100 \\
$31^{\circ} 20^{\prime}$ & 7 & $\times$ & $\bigcirc$ & $\bigcirc$ & E3 & 23.3 & $8: 57$ & 19237 \\
$31^{\circ} 28^{\prime}$ & 2 & $\times$ & $\times$ & $\bigcirc$ & C6 & 22.1 & $6: 00$ & 18862 \\
$31^{\circ} 28^{\prime}$ & 37 & $\bigcirc$ & $\times$ & $\bigcirc$ & C4 & 22.1 & $1: 45$ \\
$31^{\circ} 30^{\prime}$ & 7 & $\times$ & $\times$ & $\bigcirc$ & C10 & 22.5 & $9: 45$ & 18231 \\
$33^{\circ} 24^{\prime}$ & 57 & $\times$ & $\bigcirc$ & $\bigcirc$ & A7 & 25.2 & $23: 33$ \\
\hline
\end{tabular}

positively correlated with water temperature (Pearson's coefficient $=0.44, \mathrm{P}=0.067$ ).

\section{Laboratory experiment}

Fifty seven individuals of Halobates sericeus collected in the East China Sea were kept under long (13 females, 8 males, 9 larvae of $5^{\text {th }}$ instar) or short-day conditions (11 females, 8 males, 8 larvae of $5^{\text {th }}$ instar). Five of the 30 individuals $(16.7 \%)$ survived 20 days under long days and $29.6 \%$ of the 27 individuals under short days $\left(\chi^{2}\right.$ test: $\chi^{2}$ value $\left.=1.356, \mathrm{fd}=1, P=0.244\right)$. There was no significant difference in the survival of the adults over the 20 days in the long $(23.8 \%$ of 21 adults $)$ and short days
$(42.1 \%$ of 19 adults $)\left(\chi^{2}\right.$ test: $\chi^{2}$ value $=1.522, \mathrm{fd}=1, P=$ 0.217 ) (Fig. 3). Most insects in the sample kept at each photoperiod (5 individuals under long-days, 6 under short-days) were observed for $150 \mathrm{~min}$. For those kept under the short-day conditions, aggregation was recorded more frequently than for those under the long-days $\left(\chi^{2}\right.$ test: $\chi^{2}$ value $=16.513, \mathrm{fd}=1, P=$ 0.001) (Fig. 4a). Duration of a group was much longer under short than long-days (Mann-Whitney U-test: $\mathrm{z}=-3.554, P<$ 0.001 ) (Fig. 4b). At both photoperiods the adult Halobates sericeus skated very rapidly without interruption on the sea water surface in the aquarium. If females and males met by chance during the skating, males sometimes tried to grasp, ride on the

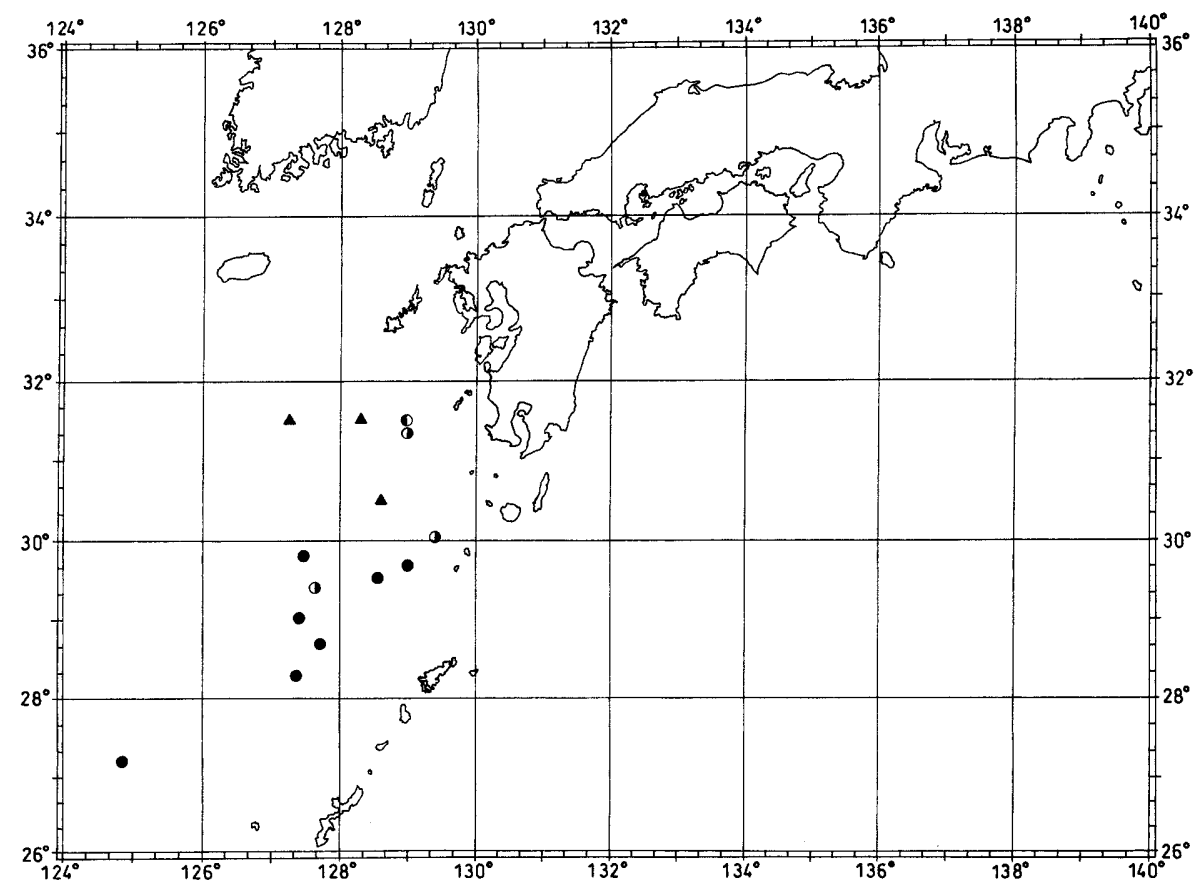

Fig. 1. Sampling locations: triangles - only Halobates sericeus collected, left-half-solid circles $-H$. sericeus and H. micans, right-half-solid circles - H. sericeus and H. germanus, and solid circles - all the three species. 


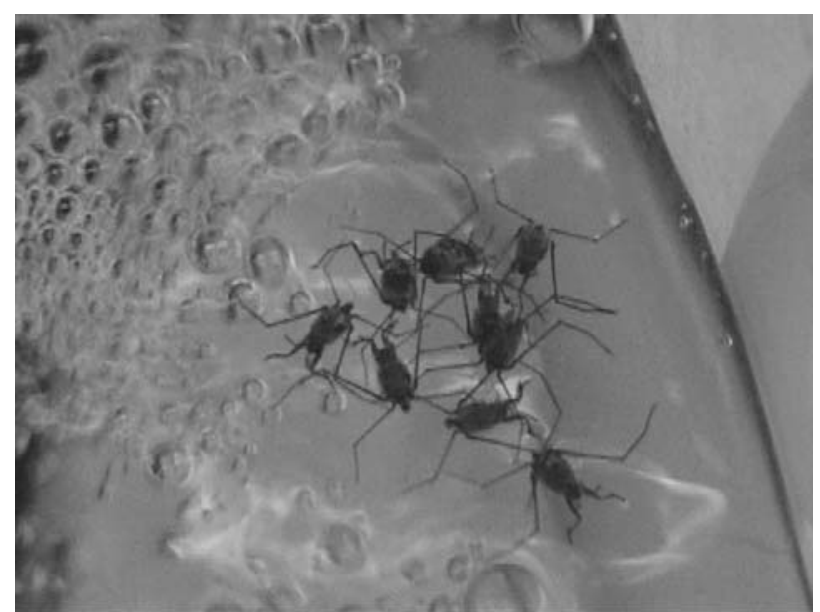

Fig. 2. An aggregation consisting of males and females.

back and mate with females (mating attempt). During a mating attempt the couple rotated at one point on the water surface for 1-10 sec. If successful, copulation lasted for 8-10 min after the rotation ceased. If unsuccessful, the male and female separated and again skated rapidly on the water surface. Mating behaviour was recorded in $58 \%$ of the 50 intervals under short and $42 \%$ of those under long-days $\left(\chi^{2}\right.$ test: $\chi^{2}$ value $\left.=2.56, \mathrm{fd}=1, P=0.11\right)$. Mating behaviour was recorded 51 times in total in $150 \mathrm{~min}$ under the short and 25 times under long-days. Only one mating was successful (duration of copulation: $9 \mathrm{~min} 40 \mathrm{sec}$ ) of the 25 mating attempts observed under long-days and only two $(7 \mathrm{~min}$ $58 \mathrm{sec}, 8 \mathrm{~min} 20 \mathrm{sec}$ ) of the 51 under short-days. This low success rate may be due to the relatively low temperature $(23 \pm$ $2^{\circ} \mathrm{C}$ ) in the laboratory. Eggs were laid by females at both photoperiods.

\section{DISCUSSION}

Three species, Halobates sericeus, H. micans and H. germanus are reported to inhabit the western area of the Pacific ocean (Cheng, 1985). However, whether the three species coexist in certain seasons is unknown. In the East-China Sea, the three species of Halobates show clear differences in the northern limits of their distributions. Miyamoto \& Senta (1960) report Halobates sericeus, $H$. micans and $H$. germanus at many locations where the water surface temperatures were $21-23^{\circ} \mathrm{C}$, $24-30^{\circ} \mathrm{C}, 27-30^{\circ} \mathrm{C}$, respectively. Higher resistance to lower temperatures in Halobates sericeus than in the other two Halobates species might account for its northern distribution

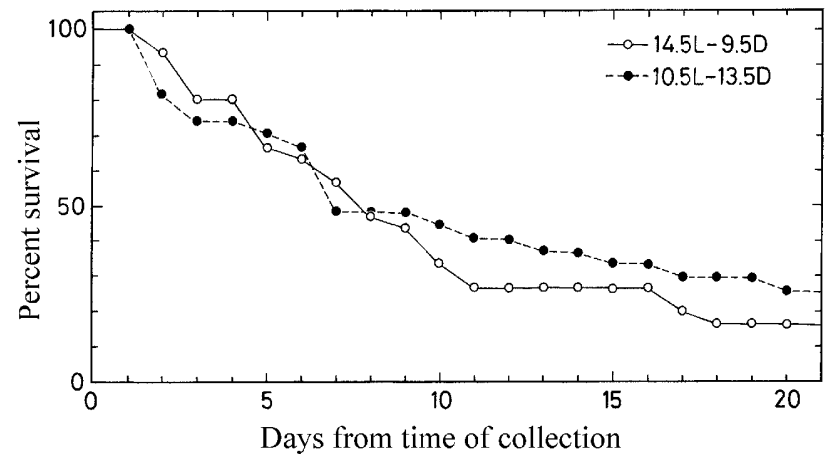

Fig. 3. Survival of adults of Halobates sericeus collected from East China Sea $\left(29^{\circ} 02^{\prime} \mathrm{N}-30^{\circ} 29^{\prime} \mathrm{N}\right)$ kept under long $(\mathrm{O})$ $(14.5 \mathrm{~L}: 9.5 \mathrm{D})$ or short $(\bullet)(10.5 \mathrm{~L}: 13.5 \mathrm{D})$ days, at $23 \pm 2{ }^{\circ} \mathrm{C}$.

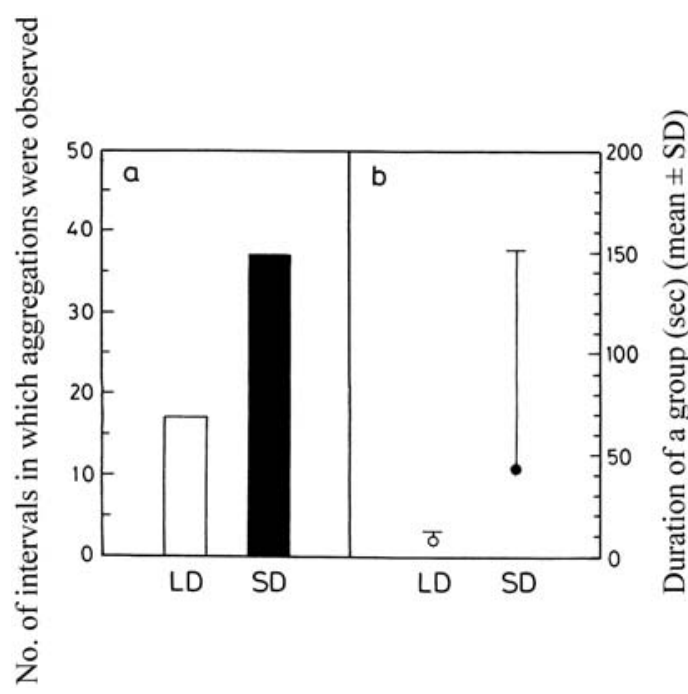

Fig. 4. The effect of short (10.5L : 13.5D - SD) and long-day (14.5L : 9.5D - LD) photoperiods on (a) the incidence of aggregation behaviour (no. of intervals in which it was observed) and (b) the duration of an aggregate (mean $\pm \mathrm{SD}$ ) in the sea skater, Halobates sericeus.

reaching $33^{\circ} 24^{\prime} \mathrm{N}$ in sea, although other environmental parameters may affect the distribution of this species.

In some terrestrial insects, reproductive diapause is linked to crowding (Tauber et al., 1986; Danks, 1987), which is advantageous for finding mates the following spring (eg. Coccinellidae beetles, Hodek \& Honěk, 1996). Crowding may be one component of the so-called diapause syndrome (Danks, 1987). However, this was not the case for the sea water strider, Halobates sericeus, because although aggregations were observed more frequently under short-days (Fig. 4), reproductive diapause was not induced by these conditions. A relative to Halobates, Metrocoris histrio, which is included in the sub-family Halobatinae, lives in fresh-water habitats. Embryos of this species enter a facultative diapause (Harada \& Wada, 2000). There is no evidence that Halobates sericeus undergoes embryonic diapause.

Short-day condition, $10.5 \mathrm{~L}: 13.5 \mathrm{D}$, promoted more frequent and longer boats of aggregation than long-days of $14.5 \mathrm{~L}: 9.5 \mathrm{D}$ (Fig. 4a,b). Aggregations seem to be observed frequently in fall and winter outdoors, and sometimes may lead to the formation of a large and immobile aggregations. How important is this behaviour in fall and winter? Grouping in winter might be advantageous for $H$. sericeus, because there is likely to be little prey (eg. zooplankton: Chen, 1985) floating on the water surface in winter and any items caught by chance can be shared by more individuals in an aggregation.

Mating behaviour was promoted more by short than longdays. In some terrestrial insects inhabiting warm-temperate or subtropical zones, aestivation is induced by long-days, thus avoiding reproduction in hot and dry seasons (Masaki, 1980). However, this may not be the case in $H$. sericeus because water temperature in the open sea can be less than $30^{\circ} \mathrm{C}$, even in mid summer. Alternatively, $H$. sericeus might reproduce throughout the year, because even in autumn and winter water temperatures are moderate in warm currents such as The Kuroshio (eg. $24^{\circ} \mathrm{C}$ in the middle of the current in December) (Harada, 2001) at relatively high latitudes, $30-40^{\circ} \mathrm{N}$.

ACKNOWLEDGEMENT. Thanks are due first to T. Ikawa and O. Takai for their help in collecting and rearing sea water striders during the cruise: KH-02-01 (2002) on The Hakuhomaru, owned by Ocean Research Institute, University of Tokyo. 
I would also like to thank T. Sugimoto (Head Scientist on Leg 1 of the cruise), T. Komatsu (Vice-Head Scientist on Leg 1) and Y. Watanabe (Head Scientist on Leg 2), Ocean Research Institute, University of Tokyo for their permission to do this study during the cruise, and their warm encouragement and help. The experimental study was also possible due to support of all of the crew and scientists on the cruise. This study was funded by a grant from The Japanese Ministry of Education, Sciences, Culture, Sports and Arts (Grant No. 11794001: 1999-2002).

\section{REFERENCES}

Andersen N.M. \& Polhemus J.T. 1976: Water-striders (Hemiptera: Gerridae, Vellidae, etc). In Cheng L. (ed.): Marine Insects. North-Holland Publishing Company, Amsterdam, pp 187-224.

Cheng L. 1985: Biology of Halobates (Heteroptera: Gerridae). Annu. Rev. Entomol. 30: 111-135.

Danks H.V. 1987: Insect Dormancy: an Ecological Perspective. Biological Survey of Canada, Ottawa, 439 pp.

Harada T. 2001: Ecological study of sea water striders, Halobates in mid-winter. In Masuzawa T. (ed.): Cruise Report of Tanseimaru Cruise. (Cruise No.: KT-01-17), Ocean Research Institute of Tokyo University, Tokyo.

HaRADA T. 2003: Hardiness to low temperature and drought in a water strider, Aquarius paludum in comparison with other insect groups. Trends Entomol. 3: 29-41.

Harada T. \& Numata H. 1993: Two critical daylengths for the determination of wing forms and the induction of adult diapause in the water strider, Aquarius paludum. Naturwissenschaften 80: 430-432.

HARADA T. \& WADA H. 2000: Life history and egg diapause of a water strider, Metrocoris histrio B. WHITE. Proceedings of XXI International Congress of Entomology. Vol. 2. Iguassu Falls, Brazil, 20-26 August 2000. p. 901

Harada T., Inoue T., Ono I., Kawamura N., Kishi M., Doi K., Inoue S. \& HodKovÁ M. 2000: Endocrine, ecophysiological and ecological aspects of seasonal adaptations in a water strider, Aquarius paludum (a mini review). Entomol. Sci. 3: 157-165.

Hodek I. \& HonĚK A. 1996: Ecology of Coccinellidae Kluwer, Dordrecht, $464 \mathrm{pp}$.

Ikawa T., Okabe H., Hoshizaki S., Suzuki Y., Fuchi T. \& Cheng L. 2002: Species composition and distribution of ocean skaters Halobates (Hemiptera: Gerridae) in the western pacific ocean. Entomol. Sci. 5: 1-6.

Masaki S. 1980: Summer diapause. Annu. Rev. Entomol. 25: $1-25$.

Miyamoto S. \& Senta T. 1960: Distribution, marine condition and other biological notes of marine water-striders, Halobates spp., in the south-western sea area of Kyushu and western area of Japan Sea. Sieboldia 2:171-186 (in Japanese with English abstr.).

SPENCE J.R. 1989: The habitat templet and life history strategies of pond skaters (Heteroptera: Gerridae): reproductive potential, phenology, and wing dimorphism. Can. J. Zool. 67: 2432-2447.

Spence J.R. \& Andersen N.M. 1994: Biology of water strides: interactions between systematics and ecology. Annu. Rev. Entomol. 39: 101-128.

Tauber M.J., Tauber C.A. \& Masaki S. 1986: Seasonal Adaptation of Insects. Oxford University Press, Oxford, 411 pp.

VEPSÄLÄINEN K. 1971: The role of gradually changing daylength in determination of wing length, alary dimorphism and diapause in a Gerris odontogaster (Zett.) population (Gerridae, Heteroptera) in South Finland. Ann. Acad. Sci. Fenn. (A, IV) 183: $1-25$.

VEPSÄLÄINEN K. 1978: Wing dimorphism and diapause in Gerris: determination and adaptive significance. In Dingle H. (ed.): Evolution of Insect Migration and Diapause. Springer, New York, pp. 218-253.

Received December 17, 2003; revised and accepted September 27, 2004 